\title{
Toward a critical heritage studies
}

\author{
Ciraj Rassool
}

Anna Karlström's article made me think of the inaugural conference of the International Association of Critical Heritage Studies held in Gothenburg in June 2012. At the conference, heritage scholars and graduate students gathered from around the world-though mainly from Britain, Australia, and Sweden - to discuss key debates in the rapidly developing, wideranging field of heritage. The location, the University of Gothenburg, was one of the most prominent sites for the new research field of heritage, as a platform for research and graduate education from about the mid-200os. The conference was organized through Swedish, British, and Australian international collaboration, with participation by the International Journal of Heritage Studies. The recent careers of two of the main organizers-Laurajane Smith and Rodney Harrison-had seen them circulate between Australia and Britain, and in Smith's case, to Sweden as well.

The main notion of "heritage studies" expressed at the conference was heritage constituted as a field, available to be researched by a disconnected outsider researcher, often through short bouts of fieldwork in that (usually African or Asian) society. This model of heritage studies rested on an almost complete bifurcation between the site of scholarship about heritage and the field site of heritage, seen as a set of practices or even an "industry." It was also apparent that, for most scholars and graduate students at the conference, the main scholarship and sources of research innovation in heritage occurred in Britain, Australasia, and Europe, and certainly not in Africa or Asia.

Karlström's work for this article seems derived mutatis mutandis from this sociology of knowledge relations: a nexus of doctoral and postdoctoral research positions in Sweden and Australia, grounding in British and Australian heritage scholarship (British- based scholars are identified as theorists or as founders of concepts), and heritage fieldwork in an Asian society (Laos). Karlström's work, though, also seemingly has an added intellectual grounding in the debates on the cultural politics of archaeological research that have occurred in the setting of the World Archaeological Congress (WAC). Scholars associated with WAC, and indeed social archaeologists more broadly, have developed more reflexive and socially aware forms of archaeological practice, especially in the context of mining and land claims. They have been alert to indigenous and local community interpretations of the sites being excavated and of artifacts being unearthed, and even open to the authority of professional archaeology being questioned. 
It is this kind of intellectual formation that has perhaps led Karlström to pose questions about the meaning and value of popular religion, spirituality, and the sacred in Laos and its implications for the "ideology" of heritage and for heritage management, considered from the base of an Australian university and from an archaeological field site in Laos. In seeking to pose questions about "heritagization" and heritage as a preservationist discourse, Karlström draws on her fieldwork in Laos to show the ever- present connections between heritage and the sacred. While "institutionalized heritage" privileged the material for the purposes of preservation and restoration, and sought to prevent the destruction or alteration of objects and sites, Karlström shows how the demolition of the edifice of an old Buddhist temple at Vat Ou Mong in Vientiane to make way for a new temple was entirely necessary to "liberate the spirits" and maintain religious beliefs and practices.

In this and other examples of an unearthed old jar and an excavated Dong Son bronze drum, Karlström shows how their significance for local people related more to the spirits that possessed them than their material significance. More generally, she says, spirits needed to be taken "seriously as constitutive elements of heritage," and instead of seeking to restore objects and structures to their "original state with focus on form and fabric," heritage managers needed "to appreciate change" and accept that "alteration or destruction sometimes may be necessary for the preservation of certain kinds of heritage." It would have helped if Karlström had heeded Smith's (2006) insight that all heritage (the meanings of sites, objects, and practices) is intangible.

While Karlström's research and line of argument about heritage and spirituality, and the material and the sacred is important, it is of course not new. In the African context, Great Zimbabwe has been the site of a significant body of research on the meanings and symbolic significance of its architectural features. One component of this research has shown how this site has been protected because of its spiritual significance and meanings long before its protection under colonial and postcolonial conservation systems. The work of Ndoro (2005), Sinamai (2003), and Fontein (2006), among others, has made a case for an African precolonial system of "protection" and indeed conservation of the site as a sacred shrine by spirit mediums long before the intervention and indeed dispossession by the organized systems of national and world heritage.

It is also unfortunate that Karlström's research has not able to draw sufficiently upon more critical approaches to "heritage" as a set of social practices involving transactions and contestations of knowledge involving differently located "experts" and "non-experts." This would mean a deeper analysis of heritage not merely as produced for the present, but as a production, involving relations of knowledge in the process of making and contesting meaning and social value. This is a framework of critical public scholarship (Karp et al. 2006) that actively seeks to relocate the domain of expertise outside the university seminar room into the site of practice and to destabilize the relations of expertise that "institutionalized," professionalized heritage inaugurates and perpetuates. 


\section{References}

Fontein, Joost. 2006. The Silence of Great Zimbabwe: Contested Landscapes and the Power of Heritage. Harare: Blue Weaver Press.

Karp, Ivan, Kratz, Corinne A., Szwaja, Lynn, and Ybarra-Frausto, Tomás, with Buntinx, Gustavo, Kirshenblatt-Gimblett, Barbara and Rassool, Ciraj, eds. 2006. Museum Frictions: Global Transformations/Public Cultures. Durham, NC: Duke University Press.

Ndoro, Webber. 2005. Your Monument, Our Shrine: The Preservation of Great Zimbabwe. Rome: ICCROM.

Sinamai, Ashton. 2003. Contested Heritage: The Socio- Political Contexts of Zimbabwe Sites in Zimbabwe, South Africa and Botswana. Unpublished MA Thesis, University of the Western Cape.

Smith, Laurajane. 2006. Uses of Heritage. London: Routledge. 